
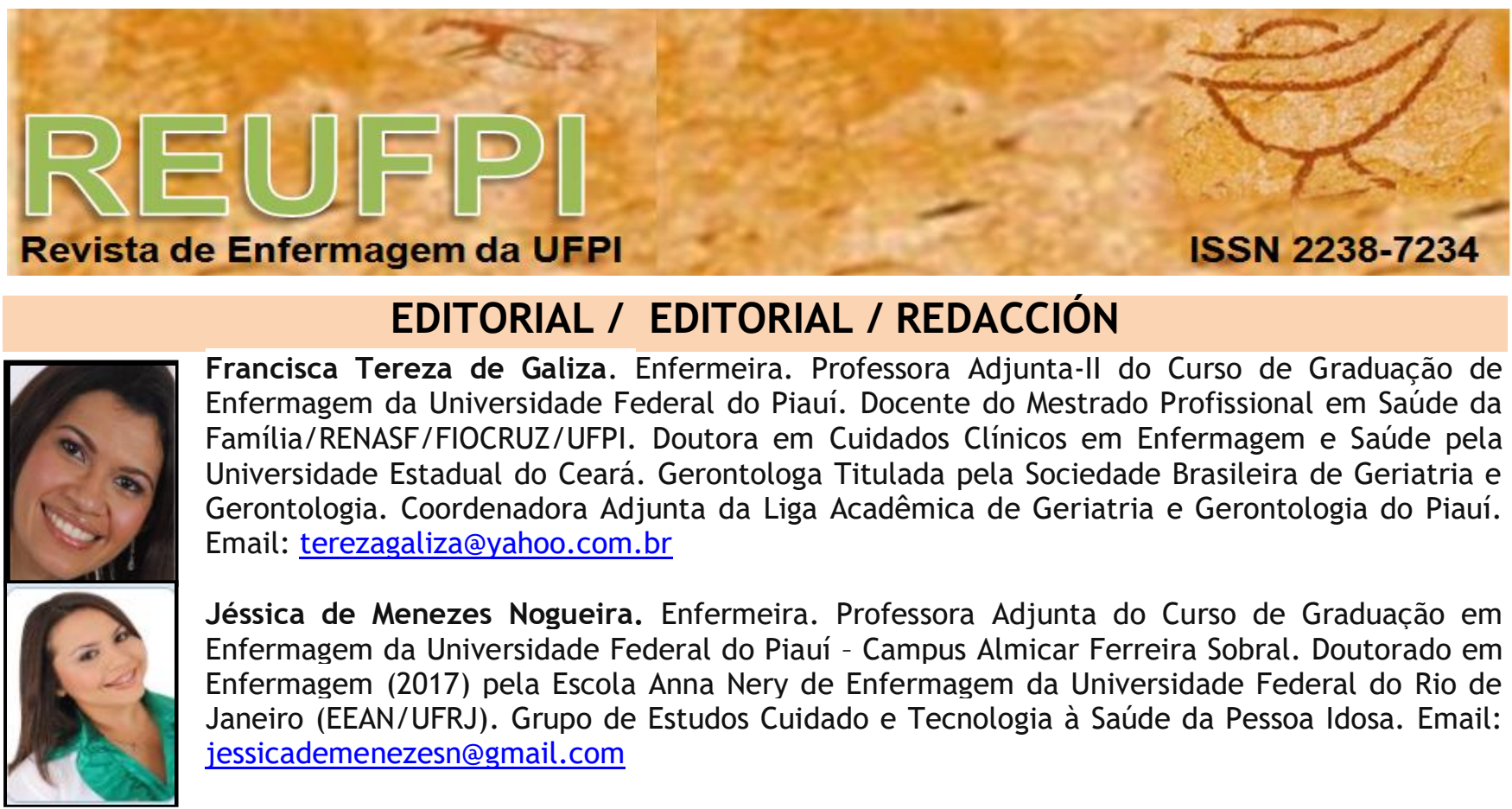

\title{
EDITORIAL / EDITORIAL / REDACCIÓN
}

Francisca Tereza de Galiza. Enfermeira. Professora Adjunta-II do Curso de Graduação de Enfermagem da Universidade Federal do Piauí. Docente do Mestrado Profissional em Saúde da Família/RENASF/FIOCRUZ/UFPI. Doutora em Cuidados Clínicos em Enfermagem e Saúde pela Universidade Estadual do Ceará. Gerontologa Titulada pela Sociedade Brasileira de Geriatria e Gerontologia. Coordenadora Adjunta da Liga Acadêmica de Geriatria e Gerontologia do Piauí. Email: terezagaliza@yahoo.com.br

Jéssica de Menezes Nogueira. Enfermeira. Professora Adjunta do Curso de Graduação em Enfermagem da Universidade Federal do Piauí - Campus Almicar Ferreira Sobral. Doutorado em Enfermagem (2017) pela Escola Anna Nery de Enfermagem da Universidade Federal do Rio de Janeiro (EEAN/UFRJ). Grupo de Estudos Cuidado e Tecnologia à Saúde da Pessoa Idosa. Email: jessicademenezesn@gmail.com

\section{COVID-19 E ENVELHECIMENTO: desafios ao enfrentar uma pandemia}

O mundo foi surpreendido, nos últimos dias, pelo alto poder de contágio do novo coronavírus (SARS-Cov-2), causador da COVID-19 - doença respiratória aguda, por vezes grave. Este vírus tem exigido dos serviços e profissionais de saúde utilizar toda sua capacidade de infraestrutura e conhecimento, para intermediar o atendimento ao número cada vez mais crescente de pessoas infectadas pelo coronavírus. Além disso, a comunidade científica e acadêmica vem desenvolvendo um árduo trabalho na elaboração de material técnico/científico para atender as demandas de entendimento e enfrentamento a essa problemática.

Ao contrário das muitas incertezas acerca dessa nova infecção, é de conhecimento que a população idosa apresenta maior vulnerabilidade às formas graves da doença e maior risco de morrer, em especial idosos frágeis, portadores de comorbidades e residentes de Instituições de Longa Permanência para Idosos (ILPIs). Estudo aponta que a curva de mortalidade tem se mostrado crescente conforme o aumento da idade, sendo de 3,6\% para idosos entre 60-69 anos, de $8 \%$ na faixa entre 70-79 anos e de $14,8 \%$ naqueles com 80 anos ou mais ${ }^{(1)}$.

Essas evidências têm implicações importantes para a organização das ações no controle da doença, e favorece o reconhecimento de algumas problemáticas frente a esse processo. Ganha destaque, a capacidade dos serviços de saúde em atender a maior procura, em especial dos mais velhos, pelo atendimento de maior complexidade, como as Unidades de Terapia Intensiva (UTIs), que dispõem de suporte ventilatório assistido e equipe altamente especializada.

Esses serviços são escassos e caros, mesmo o Brasil possuindo um alto número de leitos em UTIs, em relação a outros países desenvolvidos, não será suficiente para atender ao grande número de infectados em estado grave. 0 que brevemente, pode gerar um colapso nos serviços de saúde brasileiro.

Esse desequilíbrio entre a grande procura por atendimento de saúde e a falta de leitos e equipamentos adequados, provavelmente, obrigará aos profissionais de saúde estabelecer critérios de admissão nesses serviços, considerando maior chance de sobrevida, e também os pacientes que viverão por mais tempo após serem salvos.

Acrescenta-se, ainda, a escassez de expertises na área de geriatria e gerontologia para fornecer o atendimento mais próximo ao esperado. Ou seja, as barreiras de acesso aos serviços de saúde já existentes à população envelhecida, correm o risco de aumentar a marginalização dos idosos no país.

Outra questão a ser enfatizada, diz respeito aos idosos residentes em IPLIs. Essas instituições ganharam maior atenção da Organização Mundial de Saúde (OMS) por aglomerarem grande quantitativo da população mais afetada pela COVID-19, idosos com mais de 80 anos, frágeis e portadores de doenças crônicas. As políticas e recomendações dos órgãos internacionais e nacionais de saúde chamam atenção para os meios de prevenção e cuidados a serem prestados nesses locais, a fim de minimizar o alto índice de contágio $\mathrm{e}$, consequentemente, de letalidade que tem afetado esses ambientes ${ }^{(2)}$.

0 grande desafio tem sido a orientação de funcionários e visitantes para meios preventivos e organizacionais no funcionamento dessas instituições, diante da nova realidade vivenciada. Precárias estruturas físicas das ILPIs, escassez de equipamentos de proteção individual, lacuna no quadro de profissionais capacitados para manejo dos idosos infectados, são alguns dos fatores que preocupam as agências de saúde quanto às condições laborais e de vida nos asilos do país.

Outro aspecto a ser discutido, diz respeito à capacidade dos idosos de se adequarem às medidas 
de controle sanitário impostas pelas autoridades públicas. Muitos idosos, em especial os que vivem sozinhos ou necessitam de cuidadores, já experimentam o distanciamento social e as consequências do mesmo, como restrição para a obtenção de alimentos e outros suprimentos essenciais, além do isolamento afetivo. Com a generalização das condições de quarentena e uma frágil rede de apoio, essa população terá dificuldades para manter a qualidade de vida dentro dos parâmetros desejados ${ }^{(3)}$.

Materiais técnicos e educativos estão sendo elaborados e distribuídos pelas mídias digitais para orientar idosos, familiares e cuidadores sobre a COVID-19 e todos os aspectos envolvidos. Porém, os formuladores dessas políticas e ações devem considerar que um grande número de idosos reside em países de baixa e média renda, é analfabeto e não manuseia aparelhos de mídias digitais com maior praticidade, prejudicando, assim, na eficácia da difusão desse emergente conhecimento.

Não importa a que nível de planejamento setorial as ações estão sendo elaboradas, é fundamental atender as necessidades inerentes às diversas faixas etárias da população. É exigido, portanto, que especialistas na área de geriatria e gerontologia unam saberes e esforços para orientar as melhores condutas a serem implementadas junto aos idosos, nos seus diferentes contextos, para o enfrentamento da COVID-19. Com isso, acredita-se que essa pandemia sensibilize as autoridades em saúde para reverem as já ultrapassadas prioridades de saúde global.

\section{COVID-19 AND AGING: challenges in facing} the pandemic

The world has been surprised, in recent days, by the high contagion power of the new coronavirus (SARS-Cov-2), which causes COVID-19 - acute respiratory disease, sometimes severe. This virus has required health services and professionals to use all their infrastructure and knowledge capacity, in order to mediate the attendance to the everincreasing number of people infected with the coronavirus. In addition, the scientific and academic community has been working hard on the elaboration of technical/scientific material to meet the demands for understanding and facing this problem.

Contrary to the many uncertainties about this new infection, it is known that the elderly population is more vulnerable to severe forms of the disease and at greater risk of dying, especially frail elderly people, comorbidities, and residents of Homes for the Aged (HA). A study points out that the mortality curve has been shown to increase with increasing age, being $3.6 \%$ for the elderly between $60-69$ years old, $8 \%$ in the range between $70-79$ years old, and $14.8 \%$ in those aged 80 and over $^{(1)}$.

This evidence has important implications for the organization of actions to control the disease and helps the recognition of some problems in the face of this process. The ability of health services to meet the greatest demand, especially among the elderly, for greater complexity, such as Intensive Care Units (ICUs), which have assisted ventilatory support and a highly specialized team, stands out.

These services are scarce and expensive, even though Brazil has a high number of beds in ICUs, compared to other developed countries, it will not be enough to attend to a large number of seriously infected people. Which, briefly, can generate a collapse in Brazilian health services.

This imbalance between the high demand for health care and the lack of adequate beds and equipment will probably force health professionals to establish admission criteria for these services, considering a greater chance of survival, and also the patients who will live long after being saved.

Also, there is a shortage of expertise in the field of geriatrics and gerontology to provide the service closest to the expected. In other words, barriers to accessing health services that already exist for the aging population run the risk of increasing the marginalization of the elderly in the country.

Another issue to be emphasized is about the elderly residing in HA. These institutions gained greater attention from the World Health Organization (WHO) because they gather a large number of people affected by COVID-19, elderly people over 80 , weak, and with chronic diseases. Policies and recommendations of international and national health agencies call attention to the means of prevention and medical care provided in these areas, to minimize the high rate of contagion and, consequently, lethality that has been affecting these sites ${ }^{(2)}$.

The great challenge has been the orientation of employees and visitors towards preventive and organizational means in the functioning of these institutions, in the face of the new reality experienced. Poor physical structures of the HA, shortage of personal protective equipment, a gap in the number of professionals trained to handle infected elderly people, are some of the factors that concern health agencies regarding working and living conditions in nursing homes in the country.

Another aspect to be discussed is the ability of the elderly to adapt to health control measures imposed by public authorities. Many elderly people, especially those who live alone or need caregivers, already experienced the social distance and its consequences, such as restrictions on obtaining food and other essential supplies, in addition to emotional isolation. With the generalization of quarantine conditions and a fragile support network, this population will have difficulties to maintain the quality of life within the desired parameters ${ }^{(3)}$.

Technical and educational materials are being developed and distributed by digital media to guide the elderly, family, and caregivers about COVID-19 and all aspects involved. However, the formulators of these policies and actions must consider that a large number of elderly people live in low and middle-income countries, are illiterate, and do not handle digital media devices with greater 
practicality, thus impairing the effectiveness of the dissemination of this emerging knowledge.

No matter what level of sectoral planning the actions are being carried out, it is essential to meet the needs inherent to the different age groups of the population. Therefore, it is required that specialists in the field of geriatrics and gerontology join knowledge and efforts to guide the best conducts to be implemented with the elderly, in their different contexts, to face the COVID-19. As a result, it is believed that this pandemic will sensitize health authorities to review already outdated global health priorities.

\section{COVID-19 Y ENVEJECIMIENTO: desafíos para} enfrentar una pandemia

El mundo se ha sorprendido, en los últimos días, por el alto poder de infección del nuevo coronavirus (SARS-Cov-2), que causa COVID-19, enfermedad respiratoria aguda, a veces grave. Este virus ha requerido que los servicios de salud y profesionales utilicen toda su infraestructura y capacidad de conocimiento, para mediar la asistencia al número cada vez mayor de personas infectadas con el coronavirus. Además, la comunidad científica y académica ha estado trabajando arduamente en la elaboración de material técnico / científico para satisfacer las demandas de comprensión y enfrentar este problema.

Contrariamente a las muchas incertidumbres sobre esta nueva infección, se sabe que la población de ancianos es más vulnerable a las formas graves de la enfermedad y tiene un mayor riesgo de morir, especialmente las personas mayores frágiles con comorbilidades crónicas y los residentes de hogares para ancianos. Un estudio señala que se ha demostrado que la curva de mortalidad aumenta con el aumento de la edad, siendo 3.6\% para personas de edad avanzada entre 60-69 años, $8 \%$ en el rango entre $70-79$ años y $14.8 \%$ en los mayores de 80 años ${ }^{(1)}$.

Estas evidencias tienen implicaciones importantes para la organización de acciones para controlar la enfermedad y favorece el reconocimiento de algunos problemas frente a este proceso. Se destaca la capacidad de los servicios de salud para satisfacer la mayor demanda, especialmente entre los ancianos, de mayor complejidad, como las Unidades de Cuidados Intensivos ( $\mathrm{UCl})$, que cuentan con asistencia ventilatoria asistida y un equipo altamente especializado.

Estos servicios son escasos y caros, aunque Brasil tiene una gran cantidad de camas en $\mathrm{UCl}$, en comparación con otros países desarrollados, no será suficiente para atender el gran número de personas gravemente infectadas. Lo cual, brevemente, puede generar un colapso en los servicios de salud brasileños.

Este desequilibrio entre la gran demanda de atención médica y la falta de camas y equipos adecuados probablemente obligará a los profesionales de la salud a establecer criterios de admisión para estos servicios, teniendo en cuenta una mayor posibilidad de supervivencia, y también a los pacientes que vivirán más tiempo después de ser salvados.

Además, existe una escasez de experiencia en el campo de la geriatría y la gerontología para proporcionar el servicio más cercano al esperado. En otras palabras, las barreras para acceder a los servicios de salud que ya existen para el envejecimiento de la población corren el riesgo de aumentar la marginación de las personas mayores en el país.

Otro tema a enfatizar, concierne a los mayores que residen en hogares para ancianos de larga estancia. Estes hogares han recibido mayor atención de la Organización Mundial de la Salud (OMS) porque reúnen a un gran número de la población más afectada por COVID-19, personas mayores de 80 años, frágiles y con enfermedades crónicas. Las políticas y recomendaciones de las agencias de salud internacionales y nacionales llaman la atención sobre los medios de prevención y atención que se brindarán en estos lugares, a fin de minimizar la alta tasa de contagio y, en consecuencia, la letalidad que ha afectado estos entornos ${ }^{(2)}$

El gran desafío ha sido la orientación de los empleados y visitantes hacia medios preventivos y organizativos en el funcionamiento de estes hogares, frente a la nueva realidad experimentada. Las estructuras físicas deficientes de los hogares para ancianos, la escasez de equipos de protección personal, la brecha en el número de profesionales capacitados en el manejo de personas mayores infectadas, son algunos de los factores que preocupan a las agencias de salud con respecto a las condiciones de trabajo y de vida en hogares de ancianos en el país.

Otro aspecto a discutir, se refiere a la capacidad de las personas mayores para adaptarse a las medidas de control de salud impuestas por las autoridades públicas. Muchas personas mayores, especialmente aquellas que viven solas o necesitan cuidadores, ya experimentan aislamiento social y sus consecuencias, como restricciones en la obtención de alimentos y otros suministros esenciales, además del aislamiento emocional. Con la generalización de las condiciones de cuarentena y una red de apoyo frágil, esta población tendrá dificultades para mantener la calidad de vida dentro de los parámetros deseados ${ }^{(3)}$.

Materiales técnicos y educativos están siendo desarrollados y distribuidos por medios digitales para guiar a los ancianos, familiares y cuidadores sobre COVID-19 y todos los aspectos involucrados. Sin embargo, los formuladores de estas políticas y acciones deben considerar que una gran cantidad de personas mayores viven en países de bajos y medianos ingresos, son analfabetas y no manejan dispositivos de medios digitales con mayor practicidad, lo que perjudica la efectividad de la difusión de este conocimiento emergente.

No importa qué nivel de planificación sectorial se desarrollen las acciones, es esencial satisfacer las necesidades inherentes a los diferentes grupos 
de edad de la población. Por lo tanto, se requiere que los especialistas en el campo de la geriatría y la gerontología unan sus conocimientos y esfuerzos para guiar las mejores conductas que se implementarán con los ancianos, en sus diferentes contextos, para hacer frente a COVID-19. Como resultado, se cree que esta pandemia sensibilizará a las autoridades sanitarias para que revisen las prioridades sanitarias mundiales ya obsoletas.

\section{REFERÊNCIAS}

1. Zhou F, Yu T, Du R, Fan G, Liu Y, Liu Z, et al. Clinical course and risk factors for mortality of adult inpatients with COVID-19 in Wuhan, China: a retrospective cohort study. Lancet [internet]. 2020; 395(10229):1054-62. Disponível em:

https://doi.org/10.1016/S0140-6736(20)30566-3

2. World Health Organization, 2020. Infection Prevention and Control guidance for Long-Term Care Facilities in the context of COVID-19.

[Acessado em 6 de abr. de 2020]. Disponível em: https://apps.who.int/iris/bitstream/handle/10665/ 331508/WHO-2019-nCoV-IPC long term care2020.1-eng.pdf

3. Lloyd-Sherlock, P.; Ebrahim, S.; Geffen, L.; McKee, M. Bearing the brunt of covid-19: older people in low and middle income countries. BMJ [internet] 2020 [acessado em 7 de abr. de 2020]; 368. Disponível em: doi:

https://doi.org/10.1136/bmj.m1052

\section{Como citar este artigo:}

Galiza FT, Nogueira JM. COVID-19 E ENVELHECIMENTO: desafios ao enfrentar uma pandemia [editorial]. Rev. Enferm. UFPI [Internet]. 2020 [acesso em: dia mês abreviado ano];9:e10348. doi:

https://doi.org/10.26694/2238-7234.911-3 